\title{
Correction to: Energy-dense nutrient-poor snacks and risk of non-alcoholic fattyliver disease: a case-control study in Iran
}

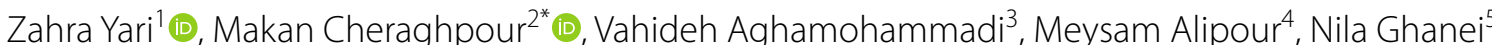
and Azita Hekmatdoost $6^{6^{*}}$

\section{Correction to: BMC Res Notes (2020) 13:221} https://doi.org/10.1186/s13104-020-05063-9

Following the publication of the original article [1] we were informed that the project No. 1398/61472 mentioned in the Acknowledgements section of the article is incorrect.

The correct project number is 20586 .

\section{Reference}

1. Yari Z, Cheraghpour M, Aghamohammadi V, Alipour M, Ghanei N, Hekmatdoost A. Energy-dense nutrient-poor snacks and risk of non-alcoholic fattyliver disease: a case-control study in Iran. BMC Res Notes. 2020;3:221. https://doi.org/10.1186/s13104-020-05063-9.

\section{Publisher's Note}

Springer Nature remains neutral with regard to jurisdictional claims in published maps and institutional affiliations.

\begin{abstract}
Author details
${ }^{1}$ Student Research Committee, Department of Clinical Nutrition and Dietetics, Faculty of Nutrition and Food Technology, National Nutrition and Food Technology Research Institute, Shahid Beheshti University of Medical Sciences, Tehran, Iran. ${ }^{2}$ Cancer Research Center, Ahvaz Jundishapur University of Medical Sciences, Ahvaz, Iran. ${ }^{3}$ Department of Nutrition, Khalkhal University of Medical Sciences, Khalkhal, Iran. ${ }^{4}$ Alimentary Tract Research Center, Imam Khomeini Hospital Clinical Research Development Unit, Ahvaz Jundishapur University of Medical Sciences, Ahvaz, Iran. ${ }^{5}$ Department of Drug Discovery and Development, Harrison School of Pharmacy, Auburn University, Auburn, USA. ${ }^{6}$ Department of Clinical Nutrition and Dietetics, Faculty of Nutrition Sciences and Food Technology, National Nutrition and Food Technology Research Institute, Shahid Beheshti University of Medical Science, Tehran, Iran.
\end{abstract}

Published online: 29 September 2020

The original article can be found online at https://doi.org/10.1186/s1310 4-020-05063-9.

*Correspondence: Bio_makan@yahoo.com; Azita.Hekmatdoost@cw.bc.ca;

a_hekmat2000@yahoo.com

${ }^{2}$ Cancer Research Center, Ahvaz Jundishapur University of Medical

Sciences, Ahvaz, Iran

${ }^{6}$ Department of Clinical Nutrition and Dietetics, Faculty of Nutrition Sciences and Food Technology, National Nutrition and Food Technology Research Institute, Shahid Beheshti University of Medical Science, Tehran, Iran

Full list of author information is available at the end of the article

(c) The Author(s) 2020. This article is licensed under a Creative Commons Attribution 4.0 International License, which permits use, sharing, adaptation, distribution and reproduction in any medium or format, as long as you give appropriate credit to the original author(s) and the source, provide a link to the Creative Commons licence, and indicate if changes were made. The images or other third party material in this article are included in the article's Creative Commons licence, unless indicated otherwise in a credit line to the material. If material is not included in the article's Creative Commons licence and your intended use is not permitted by statutory regulation or exceeds the permitted use, you will need to obtain permission directly from the copyright holder. To view a copy of this licence, visit http://creativeco mmons.org/licenses/by/4.0/. The Creative Commons Public Domain Dedication waiver (http://creativecommons.org/publicdomain/ zero/1.0/) applies to the data made available in this article, unless otherwise stated in a credit line to the data. 